\title{
On-Site Diagnosis of Transformer Winding by Frequency Response Analysis
}

\author{
Satoru Miyazaki Member (Central Research Institute of Electric Power Industry) \\ Yoshinobu Mizutani Member (Central Research Institute of Electric Power Industry) \\ Kazumichi Matsumoto Member (Kyushu Electric Power Company Inc.) \\ Shinichi Nakamura Non-member (Kyushu Electric Power Company Inc.)
}

Keywords: frequency response analysis (FRA), transformer, diagnosis of abnormality, on-site diagnosis

Displacement and/or deformation of a coil in oil-immersed transformers are hazardous. Frequency Response Analysis (FRA) has the possibility to detect these abnormalities with high sensitivity. In this paper, FRA is applied to seven oil-immersed transformers, which are installed in substations.

In FRA, transfer functions of windings are measured and abnormality of winding is detected by detecting their change compared

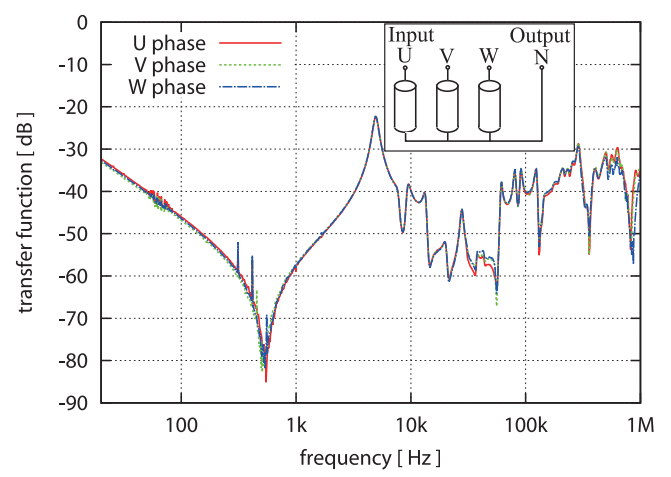

(a) Transfer function between terminal and neutral point of Y-connected winding

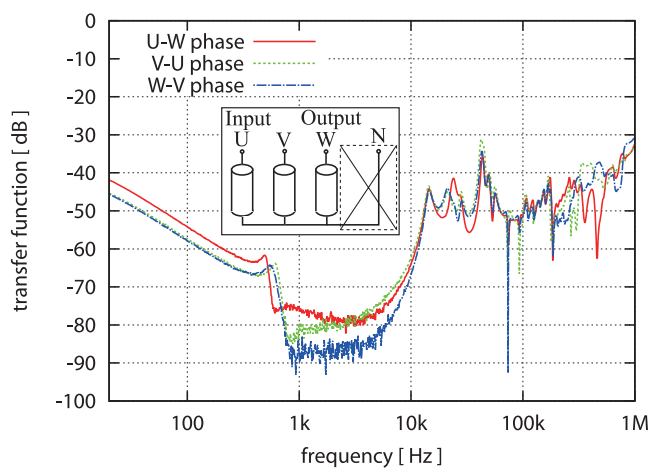

(b) Transfer function between 2 terminals Y-connected winding

Fig. 1. Phase-to-phase comparison of transfer functions with initial data measured beforehand. However, initial data of most transformers, which are under operation, had not been measured. When the initial data do not exist, it may be possible to diagnose transformer windings by comparing transfer functions of three phases (phase-to-phase comparison) or by comparing transfer functions to those of sister units (sister-unit comparison). The phase-to phase comparison is applicable when transfer functions are measured between a terminal and the neutral point of the $\mathrm{Y}$ connected windings. However, in case of transformers without the neutral point terminal, the phase-to-phase comparison is not applicable for the transfer functions measured between 2 terminals of the Yconnected windings. The sister-unit comparison is fully applicable and the performance of the comparison can be improved by additionally comparing the transfer functions phase-to-phase.

Furthermore, influence of the bus in measuring the transfer functions is evaluated. Transfer functions measured with connecting the bus to the transformer are much different from those measured when the bus is disconnected. Therefore, it is recommended disconnecting the bus from the transformer in measuring transfer functions.

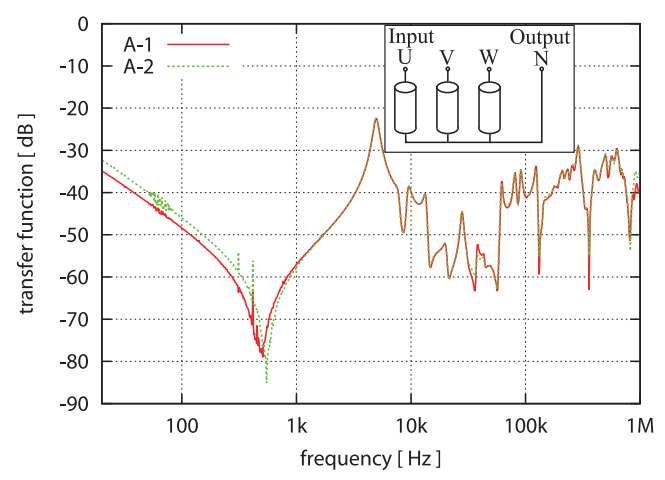

Fig. 2. Sister-unit comparison of transfer functions 


\title{
周波数応答解析による変圧器巻線異常の現地診断手法の検討
}

\author{
正員 宮嵩 悟* 正 員 水谷 嘉伸* \\ 正 員 松本 一道** 非会員 中村 信一**
}

\section{On-Site Diagnosis of Transformer Winding by Frequency Response Analysis}

Satoru Miyazaki*, Member, Yoshinobu Mizutani*, Member, Kazumichi Matsumoto**, Member, Shinichi Nakamura**, Non-member

\begin{abstract}
Displacement and/or deformation of a coil in oil-immersed transformers are hazardous. Frequency Response Analysis (FRA) has the possibility to detect these abnormalities with high sensitivity. However, a guideline for diagnosis of transformers by FRA is not yet firmly established. In this paper, FRA is applied to seven oil-immersed transformers installed in substations. Diagnosis methods when initial data do not exist are evaluated. When the initial data do not exist, it may be possible to diagnose by comparing transfer functions of three phases (phase-to-phase comparison) or by comparing transfer functions to those of sister units (sister-unit comparison). The phase-to phase comparison cannot be applied to some kinds of vector groups. The sister-unit comparison is fully applicable and the performance of the comparison can be improved by additionally comparing the transfer functions phase-to-phase. Furthermore, applicability of measurement of the transfer functions without disconnecting the bus from the transformer is evaluated. The bus should be disconnected from the transformer under tests because the measured transfer functions are influenced by bus.
\end{abstract}

キーワード : 周波数応答解析, 変圧器, 異常診断, 現地診断

Keywords: frequency response analysis (FRA), transformer, diagnosis of abnormality, on-site diagnosis

\section{1. はじめに}

変圧器で用いられている絶縁紙やプレスボードなどの絶 縁物は，熱劣化しても絶縁耐力自体はほとんど低下しない ことが知られている(1)。一方で，これらの絶縁物は構造支 持材としての役割を担っており, 熱劣化により強度が低下 する (2)。このため, 短絡事故時に発生する電磁機械力に耐 える機械的強度をこれらの絶縁物が有するかが变圧器の寿 命決定要因の 1 つとされている。絶縁紙の機械的強度を診 断するパラメータとしては, 平均重合度がある。例えば電 気協同研究会では, 平均重合度 450 を寿命レベルと定めて いる ${ }^{(3)}$ 。しかし，撤去変圧器を熱加速劣化して短絡試験を

\footnotetext{
* (財) 電力中央研究所 電力技術研究所

干 240-0196 横須賀市長坂 2-6-1

Electric Power Engineering Research Laboratiry, Central Research Institute of Electric Power Industry

2-6-1, Nagasaka, Yokosuka 240-0196

** 九州電力 (株) 大分電力所

干 870-8606 大分市金池町 2-3-4

Oita Power System Maintenance Office, Kyushu Electric Power Company, Inc.

2-3-4, Kanaike-cho, Oita 870-8606
}

行ったところ, 平均重合度 450 以下でも破壊に至らないも のもあれば, 450 程度で破壊したものもあり ${ }^{(4)}$, 変圧器の 状態に応じて寿命レベルを設定することで, 更なる寿命延 伸を図れる可能性がある。

この一方で, 短絡時に変圧器内部で発生する電磁機械力 は, 巻線の変形や位置ずれによって大きく変化する。例え ば, 変圧器輸送時の振動や衝撃, 雷サージの侵入, 地震, 経 年による絶縁物の寸法収縮などによって，これらの巻線異 常が発生する可能性がある。高経年変圧器の寿命延伸ある いは信頼度の高い運用を行うためには, このような変圧器内 部の異常現象を外部から診断する手法の開発が必須である。 変圧器巻線の変形・位置ずれなどの異常診断手法として, 周 波数応答解析 (Frequency Response Analysis : FRA) ${ }^{(5) \sim(10)}$ が着目されている。FRAでは, 例えば診断対象変圧器の巻 線インピーダンスなどの周波数特性 (以降では伝達関数と称 する）を数 $10 \mathrm{~Hz}$ 数 $\mathrm{MHz}$ まで測定し, 初期データと比べ た変化の有無で異常の有無を診断する。一方, JEC-2200 (11) では変圧器巻線の変形や位置ずれを検出する手法として, 短絡インピーダンス測定が規定されている。巻線の変形や 位置ずれが発生した場合, 主に巻線の対地容量や巻線間容 量が変化する。これらは低周波領域ではインピーダンスに 
はほとんど影響せず，高周波領域で大きく影響する。した がって，商用周波数で測定する短絡インピーダンス測定よ りも，FRAの方が高感度である。

FRA では，健全時に測定した初期データとの比較による 異常診断を基本とするため，現在運用中の変圧器に新たに 同手法を適用するにあたっては，初期データが無い場合の 診断方法の検討が必須である。また，診断に伴う変圧器停 止時間をできるだけ短くするため，現地診断における測定 の効率化が重要となる。本論文では，国内で実運用されて いる変圧器の伝達関数を測定し, 初期データが無い場合の 診断方法，測定の効率化方策について検討した結果を報告 する。

\section{FRA の基本原理}

FRA では，正弦波の電気的信号（例えば電圧）を変圧器 入力にし, 出力信号（例えば電流）の振幅測定を周波数を 変化させながら行い，その商として伝達関数（例えばイン ピーダンス）を求める。文献(9) では，伝達関数測定項目 を，電圧入力箇所および出力電圧測定箇所により 4 種に分 類している。

本論文では，伝達関数測定項目として，Fig. 1 に示すよ うに，1つの巻線の片端に電圧を入力して他端での出力電 圧を測定する端子間測定 ${ }^{(9)}$ を採用する。端子間測定におい ては, 測定しない巻線 (2 巻線变圧器での 1 次巻線測定時 の 2 次巻線， 2 次巻線測定時の 1 次巻線）を開放して測定 する場合と短絡して測定する場合があり ${ }^{(9)}$ ，以降では前者 を開放測定，後者を短絡測定と称する。

本論文の測定では，巻線端子の一端に入力した電圧を

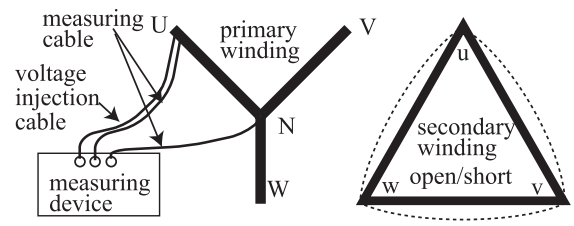

(a) $\mathrm{Y}$ connection

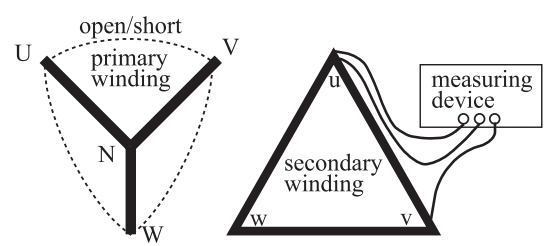

(b) $\Delta$ connection

Fig. 1. Measurement of transfer functions.
$V_{\text {input }}$, 他端で測定される電圧を $V_{\text {output }}$ とし, 伝達関数 $H(j \omega)$ を(1) 式で定義した。

$$
H(j \omega)=20 \log \frac{V_{\text {output }}(j \omega)}{V_{\text {input }}(j \omega)}
$$

ここで，jは虚数単位， $\omega$ は角周波数である。

本論文で検出対象としている巻線変形や位置ずれが発生 した場合，巻線間静電容量やインダクタンスが変化する。 静電容量やインダクタンスの変化は, 共振周波数の変化と して伝達関数にあらわれるので，伝達関数比較においては 主にこの変化に着目する。

\section{3. 伝達関数測定結果}

本論文で検討対象とした変圧器を Table 1 に示す。変圧 器名のアルファベットが同じ変圧器は, 構造が同じ同一形 式器である。

$\mathrm{Y}$ 結線の中性点が接地されている A-1 および A-2 変圧器 は，このままでは伝達関数を測定できないため，測定時に は中性点を接地から切り離した。測定対象の変圧器のうち B-1, B-2, C-1，C-2，C-3 変圧器は， 3 相 3 巻線 Y-Y- $\Delta$ 結 線の変圧器だが, 3 次巻線は安定巻線として使われており, 3 端子のうち 1 端子しか変圧器夕ンク外に出ておらず，こ の巻線を測定対象とすることができない。このため， 2 巻 線分の伝達関数しか測定していない。また，Y 結線の 1 次 巻線, 2 次巻線の中性点は非接地方式であり, 変圧器夕ン ク外に中性点端子が設けられていない。このため各相の端 子一中性点間で伝達関数を測定できないので, Fig. 2 に示す ように 2 相ずつ, $\mathrm{U}$ 相 $-\mathrm{W}$ 相間, $\mathrm{V}$ 相 $-\mathrm{U}$ 相間, $\mathrm{W}$ 相 $-\mathrm{V}$ 相 間の伝達関数を測定した。

FRA における伝達関数測定は，変圧器を停止した状態で 行う。この時, 遮断器を切っただけで, 遮断器と変圧器を 接続したままの状態では, 高周波領域では接続線と対地容 量からなる回路が形成され，接続線の特性を含んだ伝達関 数を測定してしまうことになる。この接続線の影響につい てはく4·2〉節で検討するが, さしあたって変圧器単体の伝

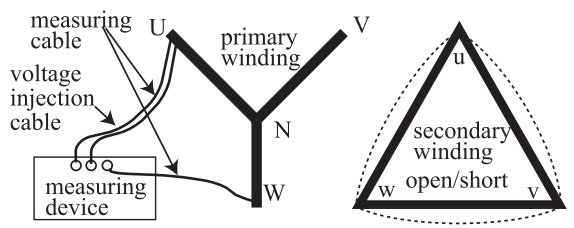

Fig. 2. Measurement of transfer functions when neutral terminal of Y connection does not exist.

Table 1. Transformers examined in this paper.

\begin{tabular}{|l|c|c|c|c|c|c|}
\hline Trsnsformer & Rated capacity & Rated voltage & Connection & Operation years & Neutral Point & \\
\hline A-1 & $180 \mathrm{MVA}$ & $220 / 110 / 66 \mathrm{kV}$ & Y-Y- $\Delta$ & 40 & grounded & \\
A-2 & & & & 38 & & \\
\hline B-1 & $20 \mathrm{MVA}$ & $66 / 6.9 \mathrm{kV}$ & Y-Y- $\Delta$ & 29 & not grounded & Tertiary winding is used as a stabilizing winding \\
B-2 & & & & 31 & & \\
\hline C-1 & & & & 31 & & \\
C-2 & $20 \mathrm{MVA}$ & $66 / 6.9 \mathrm{kV}$ & Y-Y- $\Delta$ & 31 & not grounded & Tertiary winding is used as a stabilizing winding \\
C-3 & & & & 32 & & \\
\hline
\end{tabular}




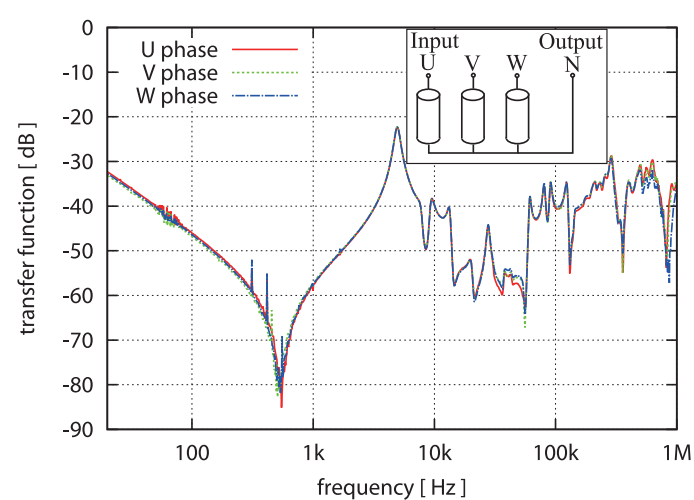

(a-i) Primary winding (Open measurement)

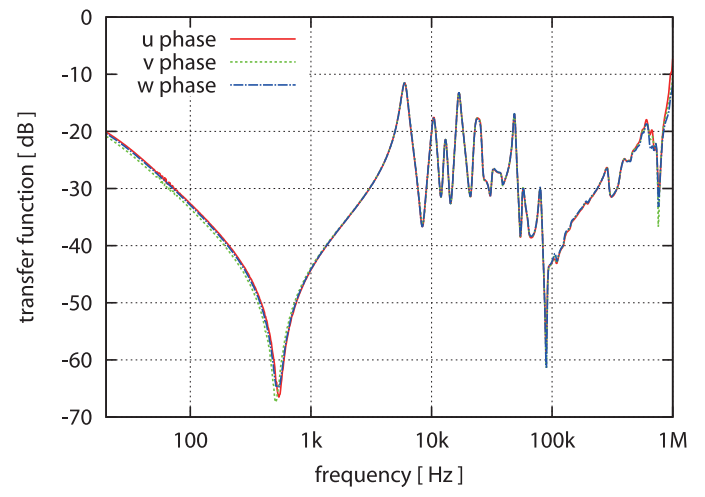

(b-i) Secondary winding (Open measurement)

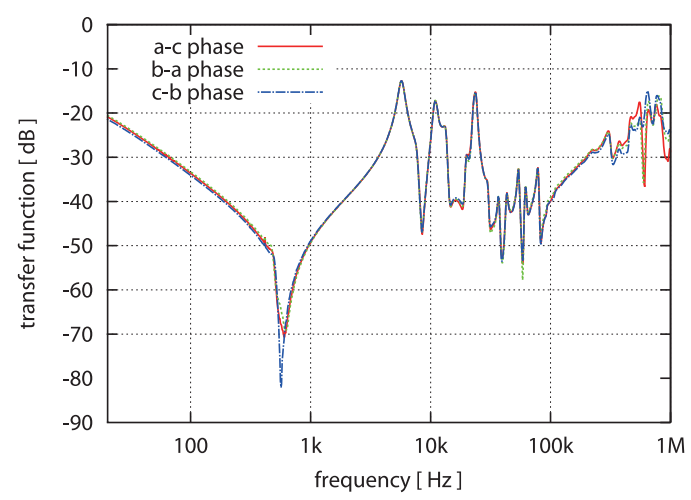

(c-i) Tertiary winding (Open measurement)

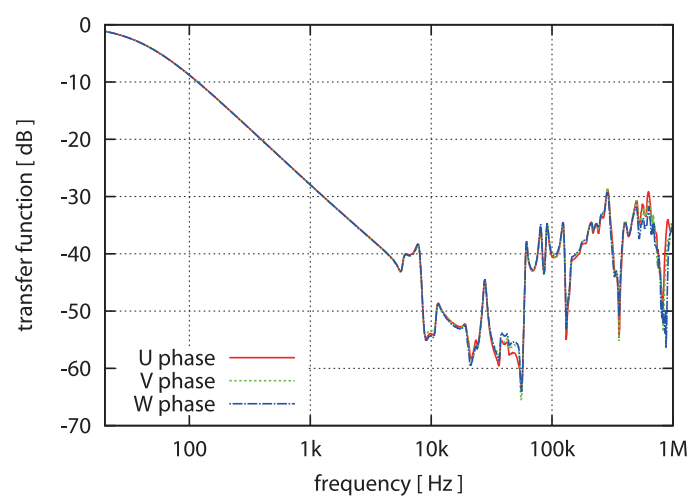

(a-ii) Primary winding (Short measurement)

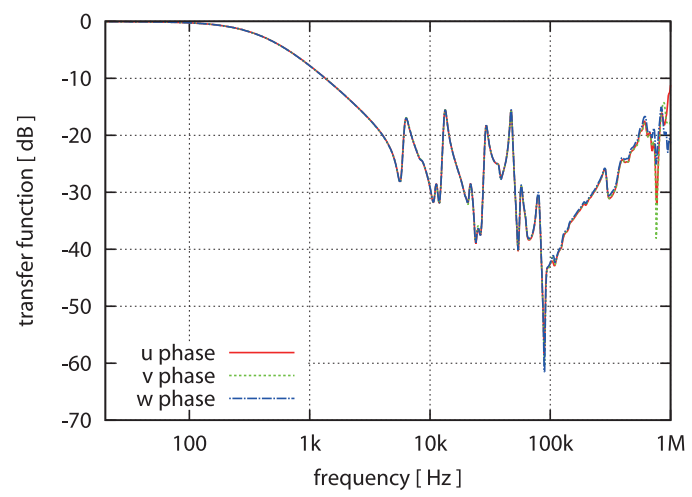

(b-ii) Secondary winding (Short measurement)

Fig. 3. Transfer functions of A-1 transformer.

達関数を測定する観点から, 变圧器ブッシング端子から接 続線を切り離した状態で測定する。

伝達関数測定には, Doble 社の M5300 (A-1, A-2, B-1, C-1, C-2 変圧器) および M5400（B-2, C-3 変圧器）を用 いた。

A-1, B-1, および C-1 変圧器の伝達関数を Fig. 3 Fig. 5 に示す。

\section{4. 考察}

〈4・1〉初期データがない場合の診断方法＼cjkstart初期デー 夕が無い場合の診断方法として，3 相変圧器の各相間比較 による診断手法と, 同型器の伝達関数比較による診断手法 が提案されている ${ }^{(8)}$ 。ここでは，実機で測定した伝達関数 を用いて，両手法の適用可能性を検討する。なお，本報告
で検討する全変圧器は, 各相間の伝達関数比較と同型器間 での伝達関数比較から総合的に判断して, 異常が発生して いないと判断した。

$\langle\mathbf{4} \cdot \mathbf{1} \cdot 1\rangle \quad 3$ 相変圧器の各相間比較による診断 3 相変 圧器の各相の巻線は同一構造であることから, 伝達関数が 一致すると考えられる。Fig. 3 に示したA-1 変圧器の伝達 関数を各相間で比較すると，よく一致している。開放測定 における第 1 共振周波数付近（Fig. 3 では $500 \mathrm{~Hz}$ 付近）は 鉄心の特性を表し ${ }^{(10)}$ ，巻線の診断にはあまり関係しない。 また， 3 次巻線の伝達関数は概ね $500 \mathrm{kHz}$ 以上の領域で伝 達関数が一致していないが，この部分は測定リード線の影 響を受けている可能性がある。なお A-1 変圧器では, 3 次 巻線端子のみ变圧器建家内部に設置されており，1次巻線 および 2 次巻線測定時とは測定器の設置位置が異なる。1 


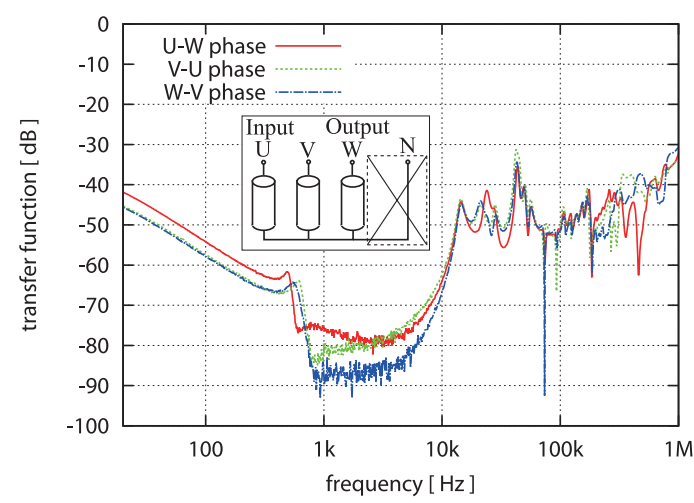

(a-i) Primary winding (Open measurement)

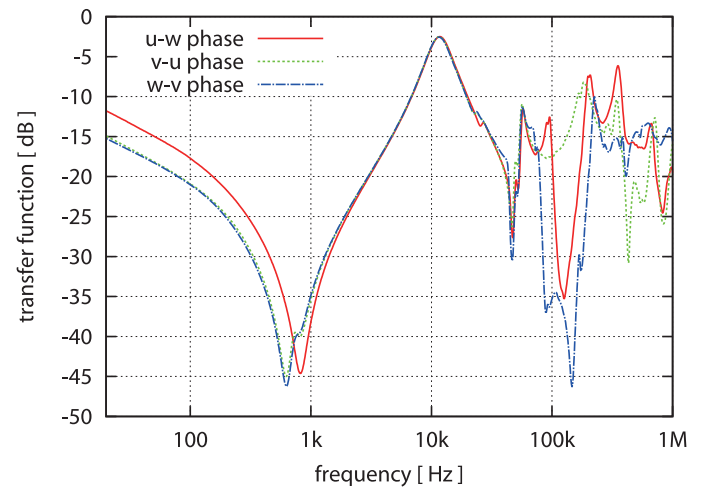

(b-i) Secondary winding (Open measurement)

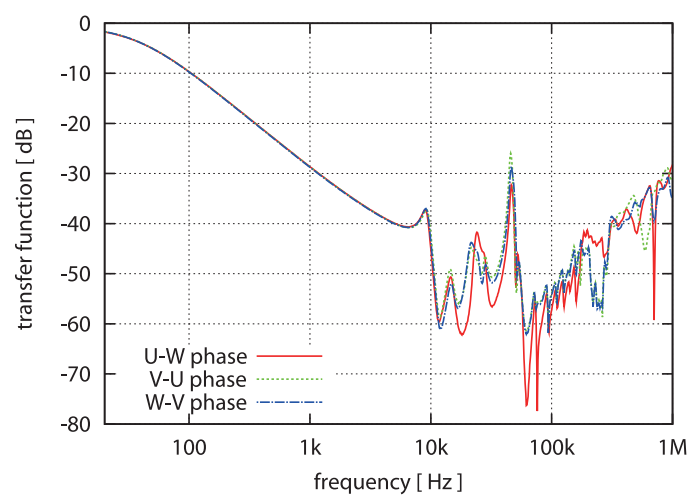

(a-ii) Primary winding (Short measurement)

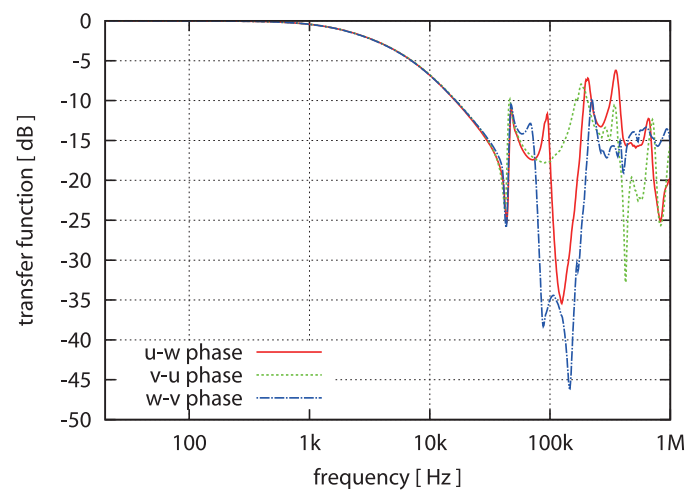

(b-ii) Secondary winding (Short measurement)

Fig. 4. Transfer functions of B-1 transformer.

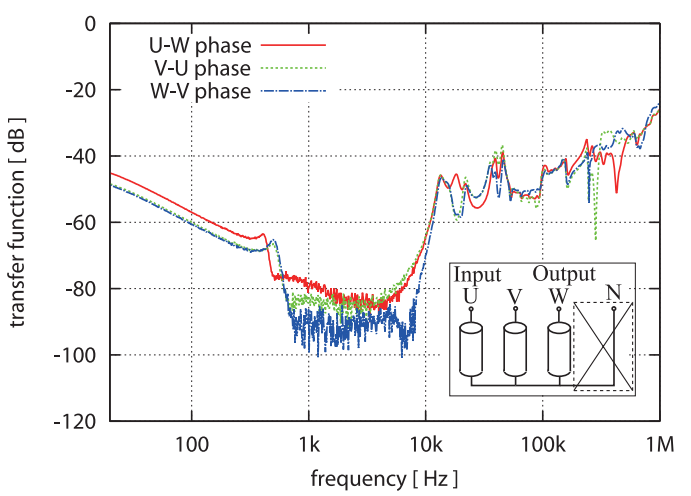

(a-i) Primary winding (Open measurement)

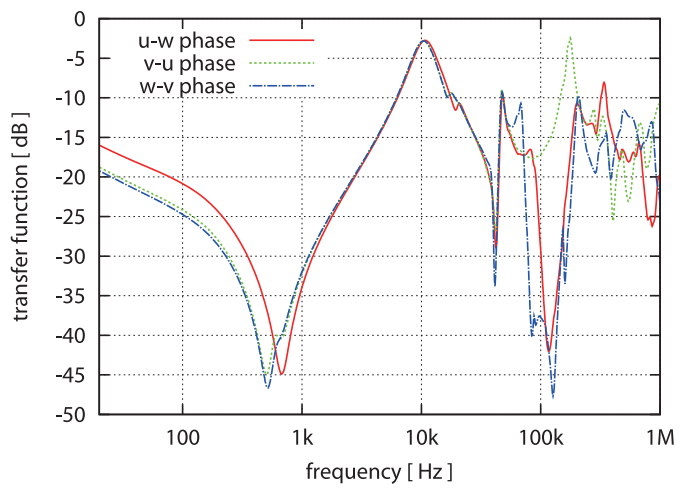

(b-i) Secondary winding (Open measurement)

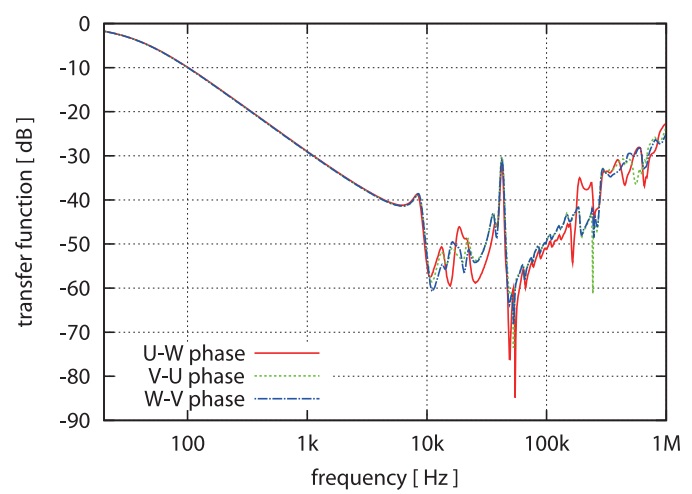

(a-ii) Primary winding (Short measurement)

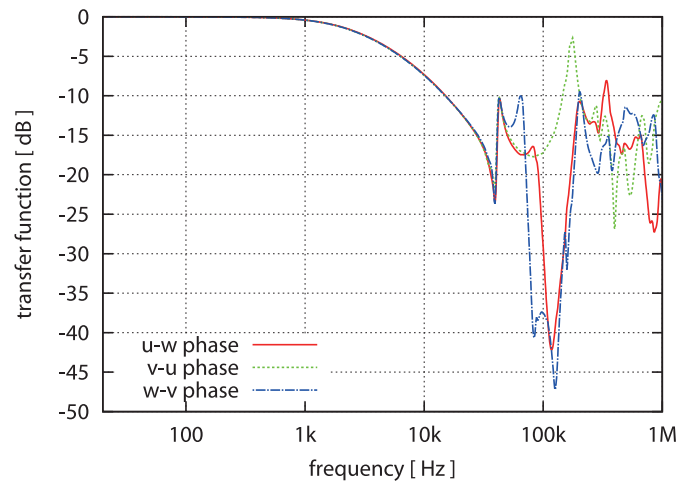

(b-ii) Secondary winding (Short measurement)

Fig. 5. Transfer functions of C-1 transformer. 


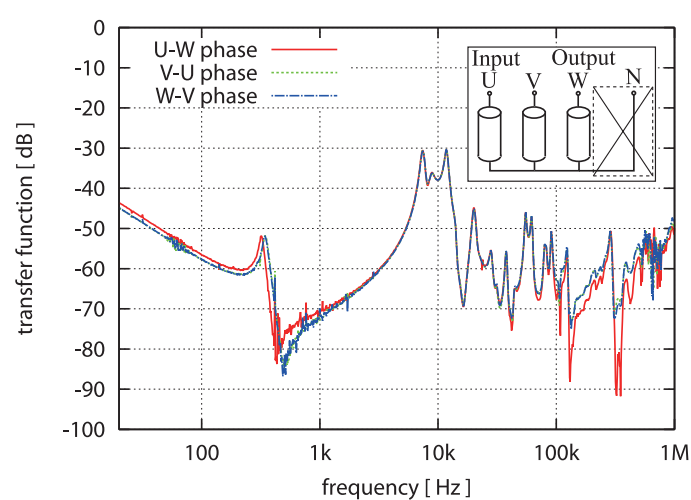

(a-i) Primary winding (Open measurement)

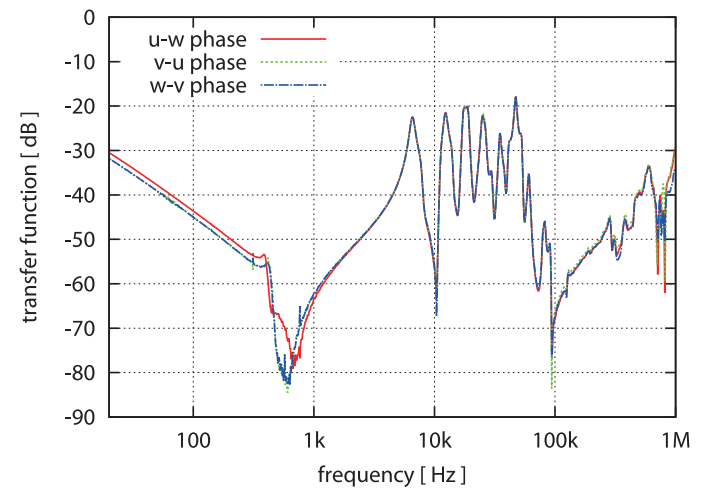

(b-i) Secondary winding (Open measurement)

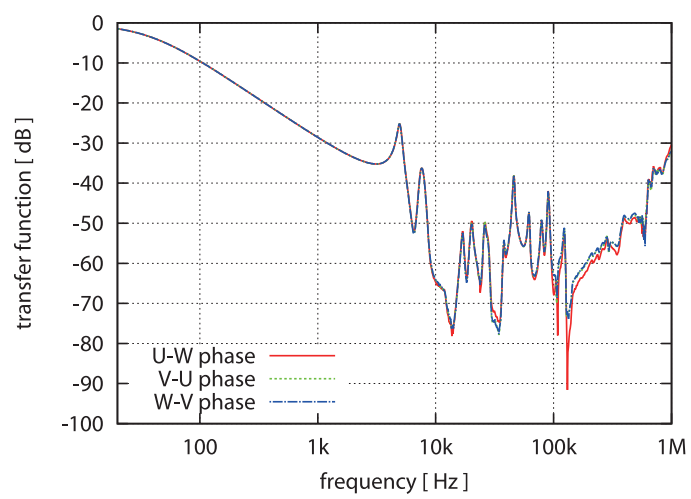

(a-ii) Primary winding (Short measurement)

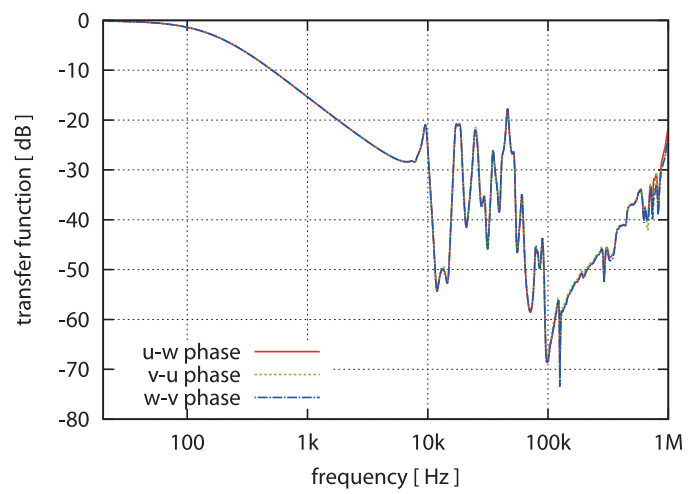

(b-ii) Secondary winding (Short measurement)

Fig. 6. Transfer functions of A-1 transformer measured by the method of Fig. 2.

次巻線の伝達関数 (Fig. 3(a-1)) は, $50 \mathrm{kHz}$ 付近で振幅が 一致していないが，診断において着目する共振周波数は一 致している。

次に, B-1（Fig. 3）㧍よびC-1 変圧器（Fig. 5）の伝達関 数を各相間で比較した場合，伝達関数は一致していない。 開放測定において, $10 \mathrm{kHz}$ 以下の周波数領域で伝達関数が 一致していないのは，各相巻線の配置により磁路長が異な るためである。

これ以上の周波数領域でも伝達関数が各相間で一致しな い要因として，Y結線の巻線を 2 相ずつ測定 (Fig. 2) してい ることが考えられる。このことを検証するため，Y 結線を 通常の方法 (Fig. 1(a)) で 1 相ずつ測定した場合に各相間で 伝達関数が一致したA-1 変圧器で, Fig. 2 の方法で測定した 伝達関数を Fig. 6 に示す。 1 次巻線では, $\mathrm{V}$ 相 $-\mathrm{U}$ 相間と $\mathrm{W}$ 相 $-\mathrm{V}$ 相間の伝達関数はよく一致しているが, $\mathrm{U}$ 相 $-\mathrm{W}$ 相間 の伝達関数はこれらと一致していない。B-1，B-2, C-1, C-2 および C-3 変圧器でも, 1 次巻線 $\mathrm{V}$ 相 $-\mathrm{U}$ 相間と $\mathrm{W}$ 相 $-\mathrm{V}$ 相間の伝達関数は比較的一致しているが， $\mathrm{U}$ 相 $-\mathrm{W}$ 相間の 伝達関数は大きく異なっており，同様の傾向を示している。 高周波領域に扔ける Y 結線と $\Delta$ 結線の等価回路例を Fig.7 に示す。 $\mathrm{Y}$ 結線の場合，高周波領域では巻線間容量による インピーダンスを考虑する必要がある。Y 結線では，U-V 相間と V-W 相間のインピーダンスは同一であり，V-U 相 間， W-V 相間の伝達関数は一致する。しかし，U-W 相間 のインピーダンスは, $\mathrm{U}-\mathrm{V}$ 相間と $\mathrm{V}-\mathrm{W}$ 相間のインピーダ

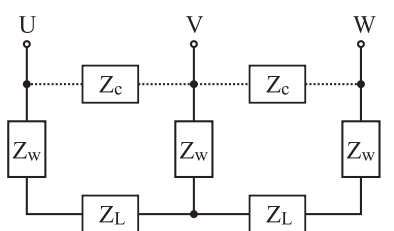

(a) Y connection

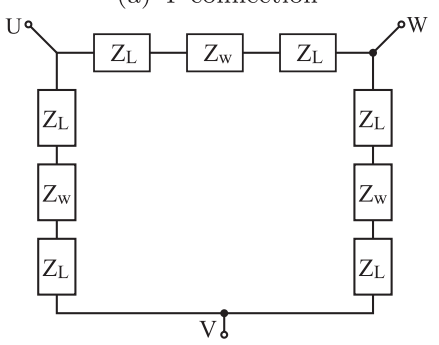

(b) $\Delta$ connection

$Z_{w}$ : Impedance of winding.

$Z_{L}$ : Impedance of connection lead of windings

$Z_{c}$ : Impedance due to inter-winding capacity.

Fig. 7. Example of circuit of 3-phase transformer in high frequency range.

ンスと異なり，伝達関数も一致しない。一方 $\Delta$ 結線では, 巻線が互いに直接接続されているので，その影響は小さい と考えられる。 $\Delta$ 結線では, どの端子間のインピーダンス も同一になり，伝達関数も一致する。

A-1 変圧器の 2 次巻線を 2 相ずつ測定した伝達関数 (Fig. 6 (b)）は, u-w 相間の伝達関数も他の 2 つの伝達関数とほぼ 


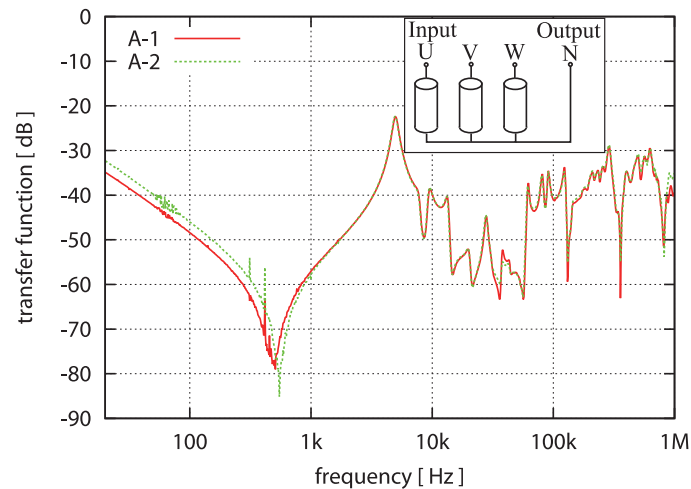

(a-i) Primary winding: U phase (Open measurement)

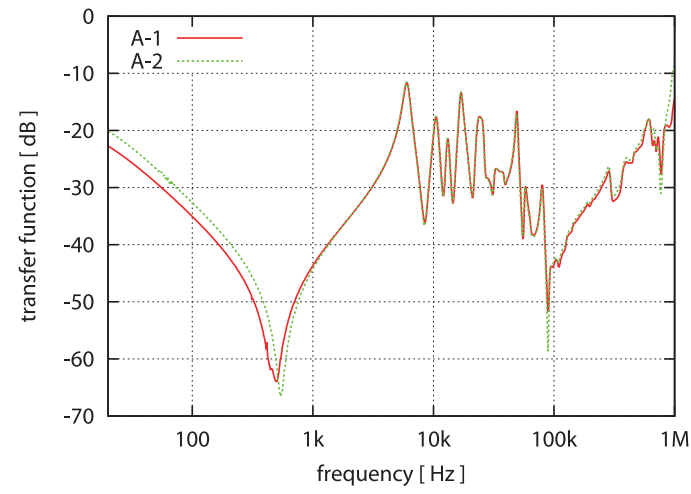

(b-i) Secondary winding: u phase (Open measurement)

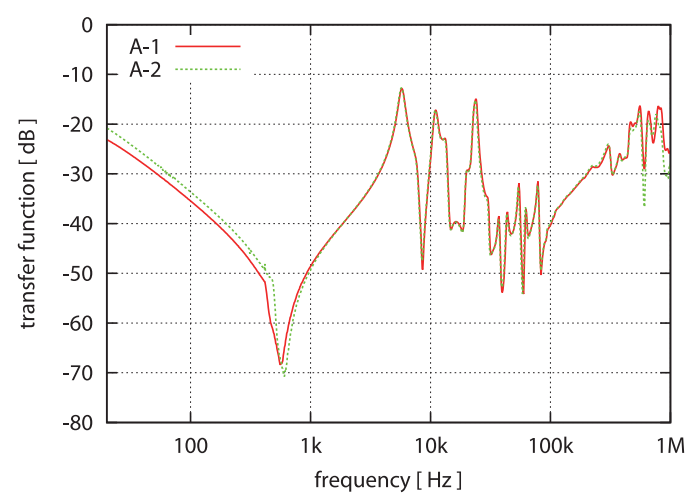

(c-i) Tertiary winding: a-c phase (Open measurement)

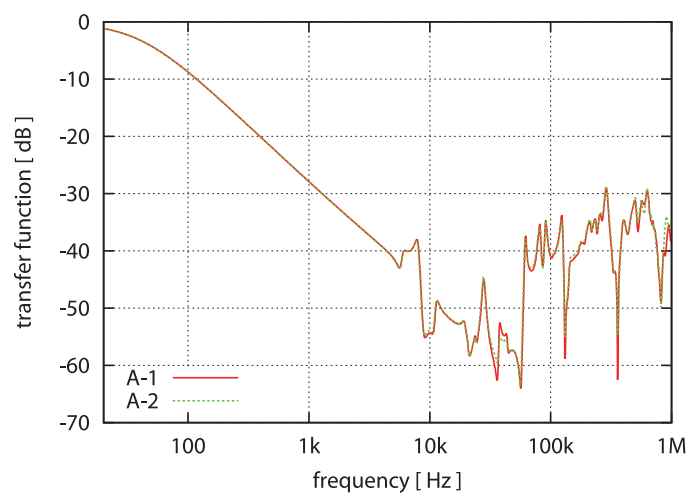

(a-ii) Primary winding: U phase (Short measurement)

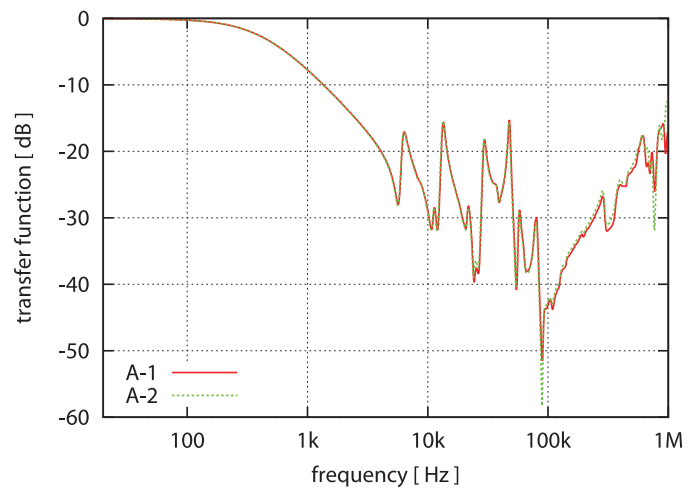

(b-ii) Secondary winding: u phase (Short measurement)

Fig. 8. Comparison of transfer functions of A-1 and A-2 transformers.

一致している。これは， 2 次巻線は 1 次巻線の内側に同心 円筒状に配置されるため，Fig. 7 の巻線間容量によるイン ピーダンスの影響が 1 次巻線よりのそれより小さいためと 考えられる。

B-1, C-1 変圧器で 2 次巻線の伝達関数が一致しないの は, これらの変圧器の 3 次巻線は安定巻線として使われて おり，3端子のうち 1 端子しか変圧器タンク外に出ていな いためである可能性がある。安定巻線が各相で同一の構造 になっていないため，同軸円筒状にその外側に巻かれた 2 次巻線, 1 次巻線との間の静電容量も各相間で同一になら ず，伝達関数が一致しないと考えられる。2次卷線の方が, 1 次巻線よりも各相間で伝達関数が大きく異なっているの は，安定巻線の直近に巻かれているため，安定巻線との間 の静電容量の影響が大きいためと考えられる。3次巻線の
3 つの端子全てが外部に引き出されている A-1，A-2 変圧 器では, 各相の伝達関数が良く一致している。

以上から, 変圧器の構造によっては各相間での伝達関数 比較による診断が適用できないことがあることが明らかに なった。今後, 変圧器の構造に応じて, 各相間の伝達関数 比較による診断が可能か，変圧器を分類できるようにデー 夕の蓄積抒よび検討を継続する必要がある。各相間で伝達 関数比較ができない例としては, 本論文での検討のほかに, 文献 (8) でZ 結線を含む場合に適用できないことが報告さ れている。ただし，同文献では，その理由については検討 されていない。

$\langle\mathbf{4 \cdot 1 \cdot 2 \rangle}$ 同型器との比較 Fig. $8 \sim$ Fig. 10 に, 本論文 で測定した変圧器伝達関数を同型器ごとに比較したものを 示す。同型変圧器の伝達関数は，ほほ一致している。開放 


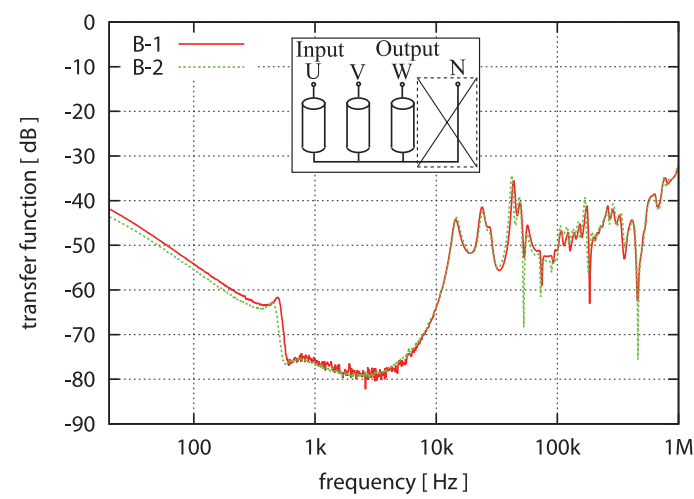

(a-i) Primary winding: U-W phase (Open measurement)

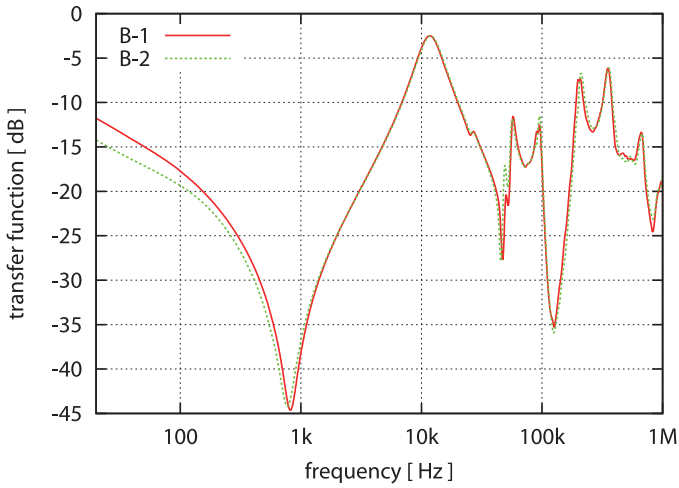

(b-i) Secondary winding: $\mathrm{u}-\mathrm{w}$ phase (Open measurement)

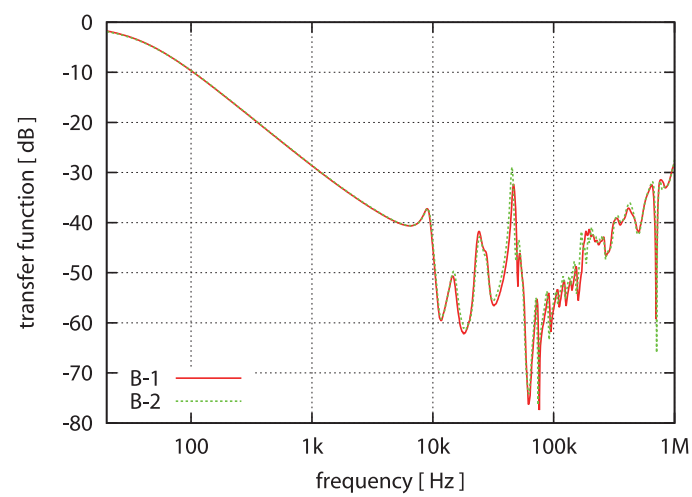

(a-ii) Primary winding: U-W phase (Short measurement)

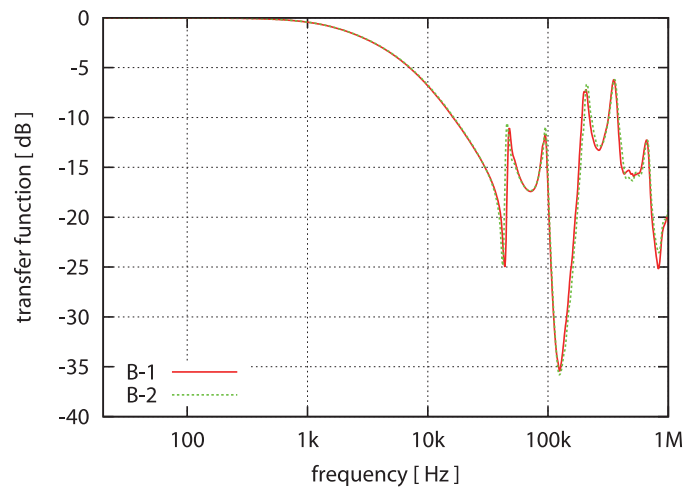

(b-ii) Secondary winding: u-w phase (Short measurement)

Fig. 9. Comparison of transfer functions of B-1 and B-2 transformers.

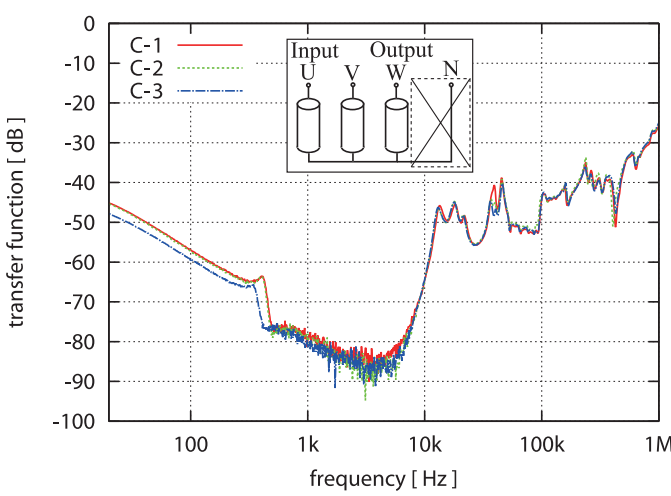

(a-i) Primary winding: U-W phase (Open measurement)

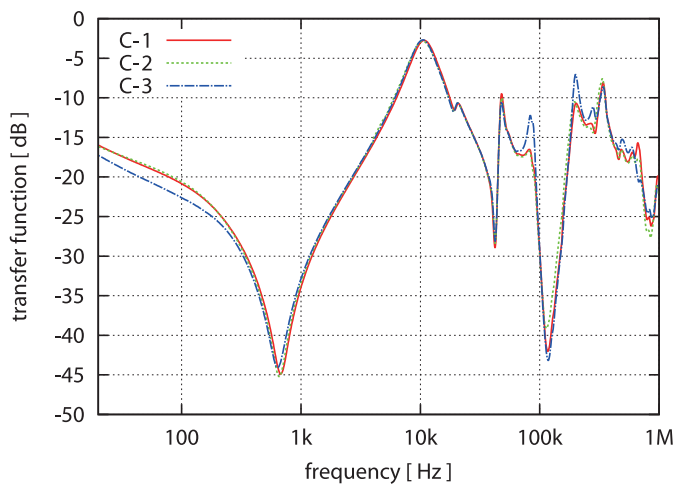

(b-i) Secondary winding: $\mathrm{u}-\mathrm{w}$ phase (Open measurement)

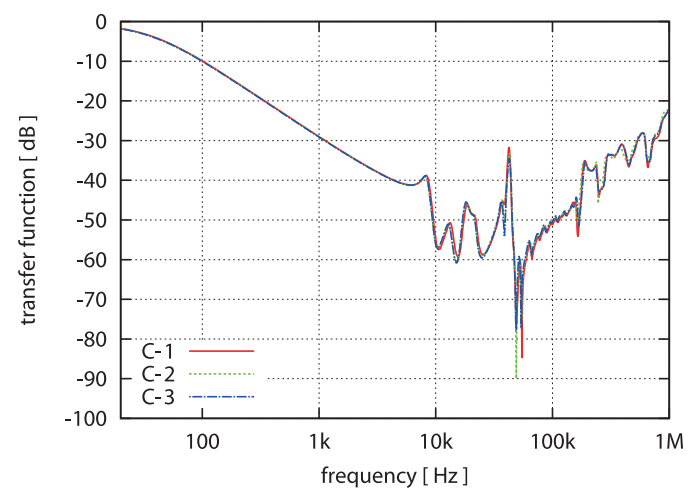

(a-ii) Primary winding: U-W phase (Short measurement)

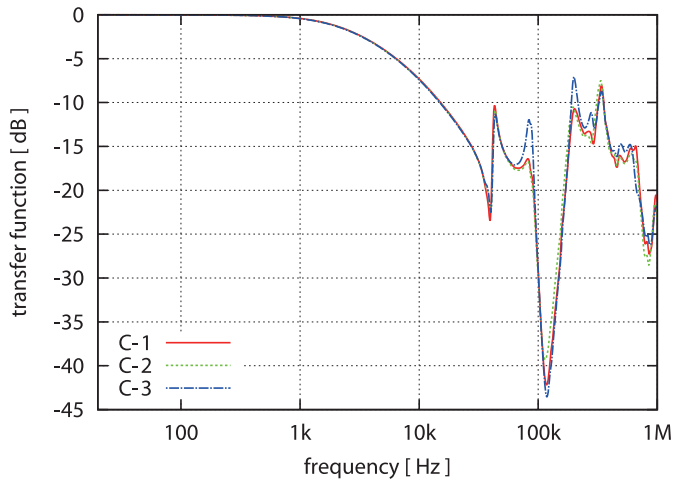

(b-ii) Secondary winding: u-w phase (Short measurement)

Fig. 10. Comparison of transfer functions of C-1, C-2 and C-3 transformers. 


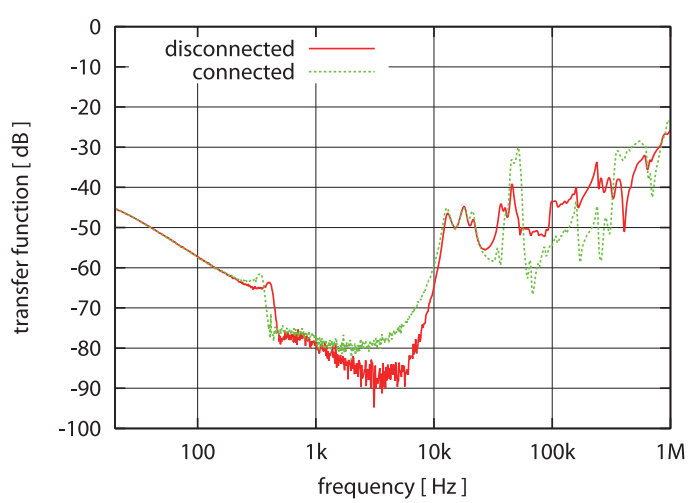

(a) Primary winding (U-W phase)

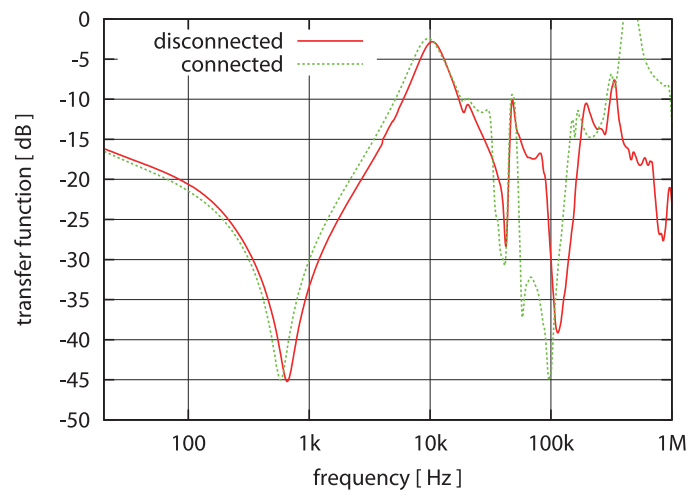

(a) Secondary winding (u-w phase)

Fig. 11. Transfer functions measured when bus is connected or disconnected to the tarnsformer. (C-2 transformer. Open measurement.)

測定した伝達関数の第 1 共振周波数がずれているのは, 鉄 心の残留磁束の影響である。例えば Fig. 8(a) では，U 相の 伝達関数が $50 \mathrm{kHz}$ 付近で一致していないが, 診断において 着目する共振周波数は一致している。以上の検討から，同 型器比較による診断を適用できる見通しが得られた。ただ し，〈4・2〉節で詳述するが，接続線としてケーブルが使用 されているなどの理由で，遮断器と変圧器を接続したまま 伝達関数を測定した場合, 同型器との比較による診断は適 用できない。

$\langle\mathbf{4} \cdot \mathbf{2}\rangle \quad$ 遮断器との接続線の影響 実運用中の変圧器を FRAにより診断する場合, 遮断器との接続線としてケーブ ルが使用されている等の理由で, 遮断器と変圧器を接続し たまま測定せざるを得ない場合もある。また，変圧器ブッ シング端子から接続線を切り離すことが可能な場合でも, 停止時間を短くする目的で接続したまま測定したいとの要 望がある。Fig. 11 に, C-2 変圧器において変圧器と遮断器 を接続した状態と変圧器ブッシング端子から接続線を切り 離した状態で測定した伝達関数を示す。接続線の有無によ り，伝達関数は大きく異なっている。

変圧器と遮断器を接続したまま測定した伝達関数は, 変圧 器と接続線両方の構造を反映していると考えられ, 同様に接 続したまま測定した初期データとの比較による異常検出は 可能と考えられる。しかし, 伝達関数変化を解釈し, 变圧器
異常様相・異常量を診断することは難しくなる。〈4·1·2〉項 では, 同型器との伝達関数比較による診断が可能と述べた が, 接続線の長さや配線方法は設置場所によって異なり, 接 続線によって伝達関数が大きく変化することから, 変圧器 を遮断器に接続したまま伝達関数を測定した場合, 同型器 との伝達関数比較による診断は適用できないといえる。以 上の考察から, 伝達関数測定時には接続線を変圧器ブッシ ング端子から切り離すことが推奨される。

通常, 変電所には複数の変圧器が設置されて㧍り, 遮断 器から変圧器ブッシング端子までは母線が近接して配線さ れることもある。やむをえない理由で, 変圧器と遮断器を 接続したまま伝達関数測定を行う場合, 稼働中の変圧器が 接続されている高電圧の母線により, FRA 試験を行う停止 中の変圧器と遮断器との接続線に, 誘導電圧が発生する可 能性があり, 注意を要する。一例として A-1 変圧器におい て, 2 次巻線のブッシング端子を遮断器と接続した状態で, 2 次巻線ブッシング端子一大地間の誘導電圧を測定した結果, $33.6 \mathrm{~V}$ であった。このように大きな誘導電圧が発生してい る場合, 測定器を保護する観点からも伝達関数測定は難し い。ただし, 上記の誘導電圧は変電所内での配線, 変圧器 の配置によるため, 誘導電圧が小さく, 伝達関数測定が可 能な場合もある。なお, Fig. 11 の伝達関数は, C-2 変圧器 のブッシング端子に発生している誘導電圧が十分小さいこ とを確認して測定した。

\section{5. おわりに}

本論文では, 実運用されている変圧器の伝達関数を測定 し, 初期データが無い場合の診断方法, 現地診断における 測定の効率化について検討した。

（1）初期データがない場合の伝達関数比較法として, 各 相間の比較および同型器との比較について検討した。

(i) 3 相変圧器の Y 結線, $\Delta$ 結線の巻線に対して Fig. 1 の方法で伝達関数を測定した場合, 各相間の比較により診 断できる見通しを得た。

(ii) $\mathrm{Y}$ 結線の中性点端子が外部に設けられていない等 の理由で, 2 相ずつ伝達関数を測定した場合, 各相間の比 較による診断は困難である。

(iii) 安定巻線の端子が 3 相全てにではなく 1 相にしか 設けられていないなど, 変圧器内部が対称な構造になって いない場合は, 各相間の比較による診断ができない可能性 が示唆された。

(iv) 同型器との伝達関数比較は, 変圧器を遮断器との接 続線から切り離し, 変圧器単体の伝達関数を測定した場合 に適用できる見通しが得られた。

（2）変圧器を遮断器に接続したままの伝達関数測定の 可否を検討した。

(i ) 変圧器を遮断器に接続したまま測定した伝達関数 は, 切り離して測定した場合に比べて大きく変化するため, 切り離した状態で伝達関数を測定する必要がある。

(ii）接続線としてケーブルが使用されている場合など, 
変圧器を遮断器から切り離すことができない場合も，初期 データとの比較による診断は可能と考えられる。この場合, 同型器との比較は適用できない。

(iii) 変圧器を遮断器に接続したまま測定する場合, 母線 の配置によっては，隣接する稼働中の母線や変圧器によっ て誘導電圧が発生することがあり，注意を要する。

(平成 21 年 7 月 23 日受付，平成 21 年 11 月 24 日再受付)

\section{文献}

(1) 矢成敏行 $\cdot$ 池田正己 ·谷口安彦・石岡康昭:「変圧器絶縁油の長期劣 化の調査結果」,電学論 B, Vol.101-B, No.12, pp.719-726 (1981-12)

(2) 石岡康昭 ·大久保仁・鈴木敏夫・本多正己:「油浸絶縁の劣化現象」, 電気学会絶縁材料研資, EIM-84-11 (1984)

（3）電気協同研究会：「油入変圧器の保守管理（その 1)」, 電気協同研究, Vol.54, No.5, p.177 (1999)

(4) E. Yajima, T. Toda, and T. Okamoto: "The Relation Shop between Deterioration and Short-circuit Strength of Oil-immersed Transformers", 1998 National Convention Record IEE Japan, No.1126 (1998-3) (in Japanese) 矢嶋栄司・戸田恒雄・岡本達希 :「油入变圧器の劣化と短絡強度の関 係」, 平成 10 年電気学会全国大会, No.1126 (1998-3)

(5) T. Sano and K. Miyagi: "Examination on Applicability of Power Transformer Diagnosis by Frequency Response Analysis", The Papers of Technical Meeting on Static Apparatus, IEE Japan, SA-06-108 (2006-12) (in Japanese)

佐野貴弘 ·宮城克徳：「周波数応答分析による電力用変圧器診断の 適用性検証」, 電気学会静止器研資, SA-06-108 (2006-12)

(6) T. Sano and K. Miyagi: "Experimental Investigation on FRA Diagnosis of Transformer Faults", IEEJ Trans. PE, Vol.127, No.7, pp.791-796 (2007-7)

(7) S.A. Ryder: "Diagnosing Transformer Faults Using Frequency Response Analysis", IEEE Electrical Insulation Magazine, Vol.19, No.2, pp.16-22 (2003)

(8) J. Christain and K. Feser: "Procedures for Detecting Winding Displacements in Power Transformer by the Transfer Function Method", IEEE Trans. Power Delivery, Vol.19, No.1, pp.214-220 (2004)

(9) "Mechanical-condition assessment of power transformer windings using Frequency Response Analysis (FRA)", CIGRE WG A2.26 Report, No.342 (2008)

(10) S. Miyazaki, Y. Mizutani, H. Suzuki, and M. Ichikawa: "Detection of Deformation and Displacement of Transformer Winding by Frequency Response Analysis", CRIEPI Report, H06003 (2007-8) (in Japanese)

宮岦 悟・水谷嘉伸・鈴木 宽・市川路晴 :「周波数応答解析を用い た変圧器巻線の変形·位置ずれ検出手法の検討」, 電中研報告, H06003 (2007)

（11）電気学会：「変圧器」, 電気規格調査会標準規格 JEC-2200-1995 (1995)
宮 㟝

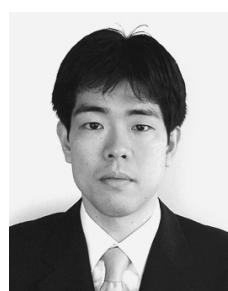

悟（正員） 1977 年 8 月 26 日生。 2006 年 3 月東京 大学大学院工学系研究科博士課程修了。同年 4 月 (財) 電力中央研究所入所。現在, 同所電力技術研 究所主任研究員。主として電力機器の診断技術, 高電圧計測に関する研究に従事。博士 (工学)。 IEEE 会員。

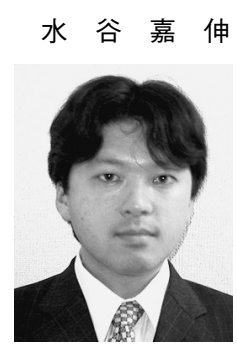

（正員） 1973 年 2 月 2 日生。 1997 年 3 月東京工 業大学大学院工学系研究科修士課程修了。同年 4 月 (財) 電力中央研究所入所。現在，同所電力技 術研究所主任研究員。主として電気絶縁材料の熱 劣化や機器の劣化診断に関する研究に従事。2003 年度, 2006 年電気学会論文発表賞受賞。

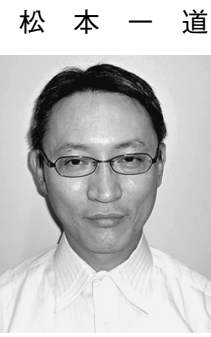

(正員) 1966 年 3 月 12 日生。 1989 年 3 月慶應 義塾大学理工学部電気工学科卒業。同年 4 月九州 電力 (株) 入社。系統計画, 電源計画, 原価戦略 などに携わる。2001〜2004 年 (社) 海外電力調査 会ワシントン事務所。現在, 同社大分電力所にて 電力供給の現場責任者として従事。1998 年電気 学会論文賞受賞。

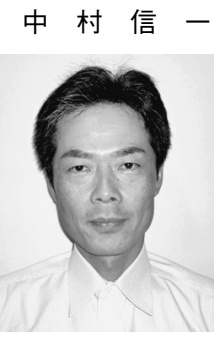

（非会員） 1964 年 11 月 20 日生。1983 年 4 月九 州電力 (株) 入社。現在，同社大分電力所にて発 変電設備の保全, 設備計画業務㧍よび保全に関す る研究開発に従事。 